\title{
Impact of modified atmospheric packaging and edible coatings on quality of minimally processed prickly pear during cold storage
}

\author{
El-Sayed Samaa M. ${ }^{{ }^{*}}$, Ahmed Nahed A. ${ }^{\mathrm{b}}$ \\ ${ }^{a}$ Food Science and Technology Department, Faculty of Home Economics, Al-Azhar University, Tanta, Egypt \\ ${ }^{b}$ Fruit Handling Department, Horticulture Research Institute, Agricultural Research Center, Giza, Egypt
}

\begin{abstract}
This study was performed to investigate the effect of different concentrations of modified atmospheric packaging (MAP) which consists of a mixture of gases $\mathrm{CO}_{2}, \mathrm{~N}_{2}$ and $\mathrm{O}_{2}$, by some treatments such as (C): $\left(60 \% \mathrm{Co}_{2} / 20 \% \mathrm{~N}_{2} / 20 \% \mathrm{O}_{2}\right)$ and (D): $\left(60 \% \mathrm{CO}_{2} / 20 \% \mathrm{~N}_{2} / 20 \% \mathrm{O}_{2}\right)$ with edible coating and under vacuum packing where the treatment; (B) compared with control sample (A) on quality attributes and prolong shelflife of minimally processed prickly pear during cold storage. All treatments were stored at $\left(4 \pm 1^{\circ} \mathrm{C}\right)$ and relative humidity (90-95\%) for 21 days and the quality parameters such as weight loss, firmness, total soluble solids (TSS), titratable acidity (TA), total caroteniods, total bacterial count, psychrophilic bacterial count, moulds and yeasts count, total colony count and sensory evaluation were done. The results observed the treatment (D) was the best for reduction of microbial load followed by treatment (C) then treatment (B) until 15 days of storage as compared to control (A) at 6 days of storage. The use of modified atmosphere packaging, either alone or in combination with the edible film, reduced the deterioration of the physiochemical characteristics of minimally processed prickly pear samples during cold storage. The obtained data indicated that the sensory evaluation, it became clear that packing in a modified atmosphere with edible coating (D) was the best, followed by packing in a modified atmosphere alone (C), which prolongs the shelf life, freshness and quality of the fruits when stored under the conditions of cooling and the relative humidity of the laboratory prickly pears which was more efficiency from storage under vacuum or without treatment as in the control sample (A). Also, these modified atmosphere packaging and edible coating showed a great influence on the quality and shelf life of the treated samples. Finally, it is evident from the results obtained that modified atmosphere packaging and edible film significantly affected the retention of the tested samples for quality characteristics in general.
\end{abstract}

Keywords: minimally processed prickly pear, modified atmospherepackaging, edible coating, physiochemicalproperties, total carotenoids, microbial eaxmination. 


\section{Introduction}

Prickly pear (Opuntia sp.) is an excellent source of antioxidant, fiber and other bioactive compounds, which give a special quality as functional food. Recently, demand for minimally processed fruits and vegetables have increased. Ready-to-eat commodities might have similar nutrition and sensory properties as whole fresh products (Artés et al., 2007). The consumption of fresh fruits and vegetables has been associated with enhanced human health because of their bioactive compounds. Minimally processed fresh-cut fruit and vegetables is a division of the food processing industry with potential to grow due to the convenience, healthiness, attractive appearance, and flavor of products (Chafer et al., 2008). Therefore, the availability of the ready-to-eat products has increased in markets and supermarkets. There is a difficulty in the process of peeling fruit makes this unattractive to the consumer who is not known how to avoid content with the many thorns that has in its shell (Tesoriere et al., 2005). Prickly pear is the fruit of the Opuntia spp., origin from Mexico. The fruit is appreciated for its flavor and juiciness. It is an oval shaped fruit that contains many seeds, a thick skin, and many prickles on the surface (Ochoa and Guerrero, 2012). Some researchers have demonstrated that the red prickly pear pulp has antioxidant compounds, such as ascorbic acid, total carotenoids, and betalains. However, the main problem with commercial marketing of prickly pears is their perishability due to the low acid and high sugar contents
(Piga et al., 2000). Effect of chitosan coatings on the physicochemical, antioxidant, microbiological, and sensorial characteristics of peeled white and red prickly pears minimally processed fresh-cut fruit is a division of the food processing industry with potential to grow due to the convenience, healthiness, attractive appearance, and flavor of products (Artés et al., 2007; Chafer et al., 2008). The envelope (packaging, wrapping or coating) plays an important role on the conservation, distribution and marketing of foodstuff. Some of its functions are to protect the product, from mechanical damage, physical, chemical and microbiological activities. Some studies have been recognized the importance of assessing the preformed matrix of edible films in order to quantify various parameters such as mechanical, optical and antimicrobial properties, since this envelope creates a modified atmosphere (MA) restricting the transfer of gases $\left(\mathrm{O}_{2}, \mathrm{CO}_{2}\right)$ and also becoming a barrier for the transfer of aromatic compounds (Osman, 2011). The three main gases used in MAP are $\mathrm{CO}_{2}, \mathrm{O}_{2}$, and $\mathrm{N}_{2}$, either singly or in combination .The first, Carbon dioxide $\left(\mathrm{CO}_{2}\right)$ is the most important gas in the MAP of foods because of its inhibit the growth of many spoilage bacteria, the degree of inhibition proportional to increasing of concentration. It is particularly effective against aerobic spoilage bacteria, such as Pseudomonas spp. The solubility of $\mathrm{CO}_{2}$ increases with decreasing temperature and therefore the antimicrobial activity of $\mathrm{CO}_{2}$ is markedly greater at lower temperatures. There is a significant implication for MAP of foods. High levels of $\mathrm{CO}_{2}$ can 
also result in increased exudate from flesh foods, and the addition of absorbent pads in the base of the package is used to compensate for this. The second, gas oxygen $\left(\mathrm{O}_{2}\right)$ promotes several types of deteriorative reactions in foods, including fat oxidation, Most of the common spoilage bacteria and fungi require $\mathrm{O}_{2}$ for growth. For these reasons, $\mathrm{O}_{2}$ is either excluded or the level set as low as possible. The third gas nitrogen $\left(\mathrm{N}_{2}\right)$ is an inert gas with no odor or taste and a low solubility in water and other food constituents, making it a useful filler gas in MAP to counteract package collapse caused by $\mathrm{CO}_{2}$ dissolving in the food. Nitrogen indirectly influences the microorganisms in perishable foods by retarding the growth of aerobic spoilage microbes, (Kaleemullah, 2002). The edible films are classified into three categories taking into account the nature of their components: hydrocolloids (containing proteins, polysaccharides), lipids (constituted by fatty acids, acyl glycerols or waxes) and composites (made by combining substances from the two categories (Donhowe and Fennema, 1994). Polysaccharide-based coatings have been used to extend the shelf-life of fruits and vegetables by reducing respiration and gas exchange due to selective permeability to $\mathrm{O}_{2}$ and $\mathrm{CO}_{2}$ (Nussinovitch, 1997; 2000). White (Opuntia albicarpa) and red (Opuntia ficus-indica) prickly pears were peeled and submerged in chitosan solutions containing different concentrations of acetic acid (1.0 or $2.5 \%)$ to obtain readyto-eat prickly pear products. Some physicochemical ( $\mathrm{pH}$, total soluble solids, color and weight loss), antioxidant (phenolic compounds and antioxidant activity), microbiological (aerobic mesophile bacteria and yeasts plus molds), and sensory (color, firmness, aroma, flavor, and overall acceptability) characteristics were assessed during 16 day of storage at $4^{\circ} \mathrm{C}$ (Ochoa-Velasco and Guerrero-Beltrán, 2014). This study aimed to investigate the effect of modified atmospheric packaging and edible coatings as a hydrophilic polymer in delaying degradation of minimally treated prickly pear by extending postharvest life and to develop a mathematical model for weight loss of minimally processed prickly pear during cold storage.

\section{Materials and methods}

\subsection{Materials}

Balady prickly pear (Opuntia ficusindica L.) cultivar Shami was obtained from experimental station of Horticultural Research Institute, Elkalubia governorate, Egypt. The substances used in this experiment were plate count agar (Coo 441/1, ADWIC Co., Egpt), ethanol (Eoo 5811, 95\%, ADWIC, Co., Egypt), sodium hydroxide (un /1823 Chemicals Co., UK), glycerin (P05650, El-Gomhouria Co., Egypt.), methylcellulose and starch (010276, Jenapharm, Germany), citric acid (8010295, ADWIC, Co., Egypt), Nisin (Acros Organics, Belgium) and calcium hypo chlorides (El-Gomhoria Co., Egypt). Soybean oil acquired from the Food Technology Research Institute, Agriculture Research Center, Egypt. 


\subsection{Methods}

\subsubsection{Gas measurements}

The gas composition inside the packages was measured by a gas analyzer, modified atmospheric packaging and edible coatings of minimally processed prickly pear were sealed by a Model Witt Oxybaby headspace Gas analyzer $\left(\mathrm{O}_{2}\right.$, $\mathrm{CO}_{2}$, and $\mathrm{N}_{2}$ ) company Sagueny Group Wittgas stored at $4 \pm 1^{\circ} \mathrm{C}$. Air packaged group was used as a control group. Analyses were done on air, under vacuum, modified atmospheric packaging and edible coatings of minimally processed prickly pear by using two packaging separately. Of course, Witt is certified according to ISO 22000. This international standard specifies a food safety system.

\subsubsection{Leakage test}

Test for the leakage of gaseous A polyamide /polyethylene gas barrier of modified atmosphere packaging and edible coating of minimally processed prickly pear by a company Wittgas (Sagueny Group) offers certified highquality systems for the leak detection of all types of product packages. You can choose between leak detection systems for sample or continuous checks - based on $\mathrm{CO}_{2}, \mathrm{~N}_{2}, \mathrm{O}_{2}$ or as a bubble test company Sagueny Group.

\subsubsection{Preparation of minimally processed prickly pear}

The prickly pear fruits were peeled using a sharp knife. The fruits was packaged in polyamide /polyethylene, then packaged in the foam tray capacity of each 3-4 fruits. All samples were kept at refrigerator $\left(4 \pm 1^{\circ} \mathrm{C}\right)$ and relative humidity $(90-95 \%)$. The cold storage was carried out in the Post-harvest Research Department, Horticulture Research Institute, Agriculture Research Center, Giza, Egypt. During storage period the samples were periodically with drown for analysis.

\subsubsection{Preparation of edible coating}

The edible coating was prepared by stirring of methylcellulose $(1.44 \mathrm{~g})$ in 75 $\mathrm{ml}$ of distilled water at $75^{\circ} \mathrm{C}$ for $10 \mathrm{~min}$, and dispersion and gelatinization of corn starch $(3.19 \mathrm{~g})$ in $75 \mathrm{~mL}$ of water at $95^{\circ} \mathrm{C}$ for $30 \mathrm{~min}$. Gelatinized starch was homogenized at $4000 \mathrm{rpm}$ for $1 \mathrm{~min}$. Glycerol $(1.16 \mathrm{~g})$ was then added to the methylcellulose and the dispersion was homogenized at $4000 \mathrm{rpm}$ for $1 \mathrm{~min}$. The components were mixed using a magnetic stirrer. Methylcellulose and prepared starch were mixed together and maintained at $75^{\circ} \mathrm{C}$ for $10 \mathrm{~min}$ under continuous stirring. Soybean oil (1.45 g) was added to the starch- methylcellulose glycerol dispersion, and the mixture was predisposed under magnetic stirrer at $75^{\circ} \mathrm{C}$ for $2 \mathrm{~min}$ before being homogenized at $4000 \mathrm{rpm}$ for $2 \mathrm{~min}$. In this trial, the described film formation solution mentioned above was modified by adding $(0.1 \mathrm{~g} / 100 \mathrm{ml})$ of Nisin. The 
emulsion was then maintained under magnetic stirrer at $75^{\circ} \mathrm{C}$ for $10 \mathrm{~min}$ (Bravin et al., 2006). Packaging with modified atmospheric packaging and edible coatings of minimally processed prickly pear was divided into four treatments: Treatment (A): as a control treatment without any modifications, Treatment (B): Under vacuum, Treatment (C): Internal gas mixing, $60 \%$ $\mathrm{CO}_{2} / 20 \% \mathrm{~N}_{2} / 20 \% \mathrm{O}_{2}$, Treatment (D): Internal gas mixture mixing, $60 \% \mathrm{CO}_{2}$ $120 \% \mathrm{~N}_{2} / 20 \% \mathrm{O}_{2}$ and edible coating. All samples were packaged with polyamide /polyethylene, then packaged in the foam tray capacity of each 3-4 prickly pear (40 gram weight fruit). All samples were kept after packaging in the refrigerator $\left(4 \pm 1^{\circ} \mathrm{C}\right)$. Polyamide /polyethylene were obtained from Tecno-plast Company, Bourge El-Arabe, Cairo, Egypt.

\subsubsection{Chemical analysis}

Moisture, total sugar, ash, fiber, protein, lipids and total solid were determined according to AOAC (2010).

\subsubsection{Active compounds and minerals}

Minerals ( $\mathrm{Na}, \mathrm{K}, \mathrm{Ca}, \mathrm{Fe}, \mathrm{Mg}, \mathrm{Cu}$ and $\mathrm{Zn}$ ) were determined by Atomic Absorption Units (GBC 932 AA) according to AOAC (2010). Ascorbic acid (Vitamin C) was determined according to AOAC (2010) and results were expressed as mg of ascorbic acid equivalents per $100 \mathrm{~g}$ (Contreras-Calderon et al., 2011).

\subsubsection{Total phenols and total flavonoids}

Total phenols content was extracted according to Kahkonen et al. (1999) and Ivanova et al. (2010) while, was determined according to Elfalleh et al. (2009) by using spectrophotometer. Total flavonoids were measured spectrophotometrically according to Djeridane et al. (2006).

\subsubsection{Weight loss}

Weight loss percentage was estimated according to the method of Han et al. (2004) then calculated using the following equation:

Weight loss $\%=$ (Initial fruit weight Stored fruit weight at sampling date) $\times 100$ / Initial fruit weight

\subsubsection{Total soluble solids}

Total soluble solids (TSS) was determined by the refractometric method at room temperature using an Abbe refractometer (carl-zeissjena) in juice pressed from a sample of homogenized fruit slices according to Konopacka and Plocharski (2004).

\subsubsection{Titratable acidity}

Titratable was measured by titration against $\quad \mathrm{NaOH} \quad(0.1 \mathrm{~N}) \quad$ using phenolphthalein a indicator according to AOAC (2010). 


\subsubsection{Texture profile analysis}

Texture profile analysis (Firmness) was determined by a universal testing machine (Cometech, B type, Taiwan) at Food Technology Research Institute, Giza, Egypt provided with software. An aluminum $25 \mathrm{~mm}$ diameter cylindrical probe was used in a compression test to penetrate to $50 \%$ depth, at $1 \mathrm{~mm} / \mathrm{s}$ speed test. The height of the peak is a measure of degree of Firmness in Newton (N) (Bourne, 2003).

\subsubsection{Total carotenoids content}

Total carotenoids content was determined in the fresh fruits according to Askar and Treptow (1993).

\subsubsection{Total bacterial count}

Total bacterial count was determined according to American Public Health Association (APHA, 1992). The microbiological examination comprised total colony count as following: Under aseptic conditions, 50 gram of each sample were added to $450 \mathrm{ml}$ of sterilized peptone water ( $1 \mathrm{gm} /$ /iter $)$ in sterilized glass blender jar and blended for $5 \mathrm{~min}$. Appropriate serial dilution were done and then $10 \mathrm{ml}$ of every sample was plated by standard microbiological pour plat technique. According to APHA (1992), all the microbiological counts were carried out in duplicates. The plates were incubated at $37^{\circ} \mathrm{C}$ for 48 hours (APHA, 1992).

\subsubsection{Psychrophilic bacterial count}

Psychrophilic bacterial count was estimated as described in typical procedure of the total bacterial count method, except incubation at $7^{\circ} \mathrm{C}$ for 5 days in refrigerator.

\subsubsection{Moulds and yeasts count}

The moulds and yeast were determined using methods of the microbiological examination of foods described by the American public Health Association (APHA, 1992) using malt extract agar medium.

\subsubsection{Total colony count}

The total colonies of bacteria were estimated using plate count agar medium. The plates were incubated at $37^{\circ} \mathrm{C}$ for 48 hours.

\subsubsection{Sensory evaluation}

Sensory evaluation was carried out to fresh and during the cold storage by 10 judges belonging to Food Engineering and Packaging Department, Food Technology Research Institute, Agricultural Research Center, Giza, Egypt. The scoring points were 30,10 and 60 for flavor, color and appearance, respectively (Deka et al., 1984).

\subsubsection{Statistical analysis}

The obtained data were subjected to the proper statistical analysis using the 
MSTAT statistical software. The mean values were compared using LSD method at $5 \%$ level and Treatments $=\mathrm{T}$ LSD Storage period $=$ S LSD (Storage period $*$ Treatments) $=\mathrm{T} * \mathrm{~S}$. The data were tabulated and statistically analyzed using factorial analyses according to the completely randomized design (Snedecor and Cochran, 1989).

\section{Results and Discussion}

\subsection{Gas measurements}

The results in Table (1) indicated that the observed that modified atmosphere packaging and edible coating of minimally processed prickly pear (Injected and enhanced products) was the highest level after 18 and 21 days with treatments $\mathrm{C}$ and $\mathrm{D}$, while the lower level was found with treatment $B$ after 15 days as compared to treatment $A$ at 6 days of cold storage for both seasons. Efficiency of carbon dioxide $\left(\mathrm{CO}_{2}\right)$ is characterized the kept highly activates of solubility and concentration property of fat content, which works to expel oxygen and their replacement, thus concentration reduction of oxygen in the fatty substances and ability, reduce oxidation processes and improve the overall appearance of the product and separation of slides minimally processed prickly pear oxygen activates the growth of aerobic bacteria, but inhibits the growth of non-aerobic bacteria, and oxygen is important for fresh prickly pear. Nitrogen is an inert gas that is not soluble in both water and fat. It is used to replace oxygen in containers, oxidation delaying and inhibits the growth of air microbial. Also, nitrogen is an inert gas that is maintained on the package from degradation that may be occurring during handling food products. According to Kaleemullah (2002) and Hunt and Mohan (2008) these gases have the preservative effects on the packed minimally processed prickly pear. Their effect on microbial changes of product throughout the storage period highly depends on type gas internal package atmospheric and packaging materials, appropriate gas composition, storage (Masniyom, 2011). However, it is acknowledged that the respiration of the enclosed food material, biochemical reactions and slow-moving gases in and out of the packaging materials would lead to the changes in gaseous atmosphere throughout the storage period which can affect the expected shelf life (Velu et al., 2013) and when testing the Leakage test, it was he found that there was no detections of gas leakage test or bubbles was found from analysis of the tested parameters for the packaging materials used for internal package atmosphere are gas proof with polyamide /polyethylene films for packed minimally processed prickly pear.

\subsection{Physicochemical characteristics}

\subsubsection{Chemical composition}

Data in Table (2) showed that prickly pear fruits contained moisture (83.82 and 
$86.2 \%$ ), total solid (16.18 and $13.8 \%$ ), composition of prickly pear may be due total sugars (12.08 and 14.9), ash (0.82 to the different environmental conditions and $0.98 \%$ ), fiber $(4.15$ and $3.38 \%)$, during two seasons. Total sugars content protein $(0.72$ and $0.85 \%)$ and lipids $(0.57$ of prickly pear was increasing the and $0.43 \%$ ) for season 2019 and 2020, sensory quality represented in the respectively. These results are in sweetness obtained these sugars, in agreement with those obtained by Cota- addition to the nutritional value of the Sánchez (2015) and Jambi Hanan (2017). other ingredients.

These differences in chemical

Table (1): Gas composition of internal modified atmospheric packaging andedible coatings of minimally processed prickly pear duringcoldstorageat $\left(4 \pm 1^{\circ} \mathrm{C}\right)$.

\begin{tabular}{|c|c|c|c|c|c|c|c|c|c|c|c|c|}
\hline \multirow{3}{*}{$\begin{array}{l}\text { Storage period } \\
\text { (days) }\end{array}$} & \multicolumn{12}{|c|}{ Season 2019} \\
\hline & \multicolumn{3}{|c|}{ A } & \multicolumn{3}{|c|}{ B } & \multicolumn{3}{|c|}{$\mathrm{C}$} & \multicolumn{3}{|c|}{$\mathrm{D}$} \\
\hline & $\mathrm{Co}_{2} \%$ & $\mathrm{~N}_{2} \%$ & $\mathrm{O}_{2} \%$ & $\mathrm{Co}_{2} \%$ & $\mathrm{~N}_{2} \%$ & $\mathrm{O}_{2} \%$ & $\mathrm{Co}_{2} \%$ & $\mathrm{~N}_{2} \%$ & $\mathrm{O}_{2} \%$ & $\mathrm{Co}_{2} \%$ & $\mathrm{~N}_{2} \%$ & $\mathrm{O}_{2} \%$ \\
\hline 3 & 0.5 & 78.7 & 20.8 & 0.04 & 0.2 & 0.04 & 60.0 & 20.0 & 20.0 & 59.5 & 20.4 & 20.4 \\
\hline 6 & 0.4 & 78.2 & 20.0 & 1.0 & 1.5 & 1.2 & 56.2 & 19.5 & 19.8 & 57.2 & 19.6 & 20.2 \\
\hline 9 & $\mathrm{R}$ & $\bar{R}$ & $\bar{R}$ & 1.6 & 1.9 & 1.8 & 54.4 & 18.5 & 19.5 & 56.2 & 18.7 & 20.0 \\
\hline 12 & $\mathrm{R}$ & $\mathrm{R}$ & $\mathrm{R}$ & 2.0 & 2.1 & 2.0 & 53.8 & 17.8 & 18.7 & 54.5 & 17.6 & 19.8 \\
\hline 15 & $\mathrm{R}$ & $\mathrm{R}$ & $\mathrm{R}$ & 3.6 & 3.4 & 3.2 & 52.6 & 17.5 & 18.4 & 52.3 & 17.5 & 19.2 \\
\hline 18 & $\mathrm{R}$ & $\mathrm{R}$ & $\mathrm{R}$ & $\mathrm{R}$ & $\mathrm{R}$ & $\mathrm{R}$ & 50.20 & 16.8 & 18.0 & 51.8 & 16.6 & 18.6 \\
\hline 21 & $\mathrm{R}$ & $\mathrm{R}$ & $\mathrm{R}$ & $\mathrm{R}$ & $\mathrm{R}$ & $\mathrm{R}$ & $\mathrm{R}$ & $\mathrm{R}$ & $\mathrm{R}$ & 51.0 & 16.0 & 18.2 \\
\hline \multicolumn{13}{|c|}{ Season 2020} \\
\hline 3 & 0.5 & 78.6 & 20.9 & 0.4 & 0.3 & 0.05 & 59.6 & 19.8 & 20.6 & 59.0 & 19.4 & 20.6 \\
\hline 6 & 0.3 & 77.6 & 20.0 & 1.5 & 1.9 & 1.1 & 58.8 & 19.5 & 19.3 & 58.6 & 19.0 & 20.0 \\
\hline 9 & $\mathrm{R}$ & $\mathrm{R}$ & $\mathrm{R}$ & 1.8 & 2.0 & 1.9 & 57.5 & 18.6 & 19.2 & 56.8 & 18.8 & 19.8 \\
\hline 12 & $\mathrm{R}$ & $\mathrm{R}$ & $\mathrm{R}$ & 2.5 & 2.6 & 2.4 & 55.2 & 18.5 & 18.5 & 54.6 & 18.0 & 19.6 \\
\hline 15 & $\mathrm{R}$ & $\mathrm{R}$ & $\mathrm{R}$ & 3.7 & 3.8 & 3.0 & 52.5 & 17.6 & 18.0 & 52.3 & 17.6 & 19.0 \\
\hline 18 & $\mathrm{R}$ & $\mathrm{R}$ & $\mathrm{R}$ & $\mathrm{R}$ & $\mathrm{R}$ & $\mathrm{R}$ & 49.9 & 16.6 & 17.8 & 51.4 & 17.2 & 18.6 \\
\hline 21 & $\mathrm{R}$ & $\mathrm{R}$ & $\mathrm{R}$ & $\mathrm{R}$ & $\mathrm{R}$ & $\mathrm{R}$ & $\mathrm{R}$ & $\mathrm{R}$ & $\mathrm{R}$ & 49.6 & 16.5 & 18.0 \\
\hline
\end{tabular}

$\mathrm{A}=$ Control, $\mathrm{B}=$ Under vacuum, $\mathrm{C}=$ Mixing, $60 \% \mathrm{CO}_{2} / 20 \% \mathrm{~N}_{2} / 20 \% \mathrm{O}_{2}$, D = Mixing, $60 \% \mathrm{CO}_{2} / 20 \% \mathrm{~N}_{2} / 20 \% \mathrm{O}_{2}+$ Edible coating, $\mathrm{R}=$ rejected.

Table (2): Chemical composition of minimally processed prickly pear.

\begin{tabular}{|l|l|l|}
\hline \multirow{2}{*}{ Components } & \multicolumn{2}{|c|}{ Percentage (\%) } \\
\cline { 2 - 3 } & Season 2019 & Season 2020 \\
\hline Moisture & 83.82 & 86.2 \\
\hline Total solids & 16.18 & 13.8 \\
\hline Total sugars & 12.08 & 14.9 \\
\hline Ash & 0.82 & 0.98 \\
\hline Fiber & 4.15 & 3.38 \\
\hline Protein & 0.72 & 0.85 \\
\hline Lipids & 0.57 & 0.43 \\
\hline
\end{tabular}

\subsubsection{Active compounds}

The obtained data from Table (3) revealed that prickly pear contained minerals as (Ca: 39.45 and 43.18), (Fe: 0.17 and 0.24$)$, (Na: 7.15 and 12.02), (K: 
124.10 and 117.8) and (Mg: 35.7 and important compounds as vitamin C, total $31.15) \mathrm{mg} / 100 \mathrm{~g}$ for seasons 2019 and flavonoids and total polyphenols are 2020, respectively. Also, another found in prickly pear.

Table (3): Active compoundsof prickly pear.

\begin{tabular}{|l|l|l|}
\hline \multirow{2}{*}{ Active compounds } & \multicolumn{2}{|c|}{ Prickly pear } \\
\cline { 2 - 3 } & Season 2019 & Season 2020 \\
\hline Minerals (mg/100g) & 39.45 & 43.18 \\
\hline $\mathrm{Ca}$ & 0.17 & 0.24 \\
\hline $\mathrm{Fe}$ & 7.15 & 12.02 \\
\hline $\mathrm{Na}$ & 124.10 & 117.8 \\
\hline $\mathrm{K}$ & 35.7 & 31.15 \\
\hline $\mathrm{Mg}$ & 18.77 & 22.14 \\
\hline Vitamins (mg/100g) & 4.15 & 7.11 \\
\hline Ascorbic acid & 195.12 & 200.4 \\
\hline Antioxidant compounds & \multicolumn{2}{|l}{} \\
\hline Total flavonoids (g/100g) & \\
\hline Total phenolics (mg gallic acid equivalents /100g) & 15 \\
\hline
\end{tabular}

Which were 18.77 and $22.14 \mathrm{mg} / 100 \mathrm{~g}$, 4.15 and $7.11 \mathrm{~g} / 100 \mathrm{~g}$ and 195.12 and $200.4 \mathrm{mg}$ gallic acid equivalents $/ 100 \mathrm{~g}$, respectively. It observed from the same table some differences between all compounds which may be due to growing conditions during two seasons. These findings are in agreement with Gissler and Powers (2010) and Belviranl et al. (2019). From the previous results clearly evident that prickly pear is a good source in minerals and active compounds which work as antioxidants. So, it was concluded that prickly pear fruit is useful for health and prevent from the diseases.

\subsubsection{Weight loss}

Weight loss was significantly $(\mathrm{p} \geq 0.05)$ increased with the prolongation of the cold storage period for all treatments (Table 4). Normally, the weight loss occurs during the prickly pear fruits storage due to its respiratory process, the transference of humidity, and some processes of oxidation. Edible coatings are selective barriers to $\mathrm{O}_{2}$ and $\mathrm{CO}_{2}$, modifying internal atmospheres and slowing down the respiration rate of fruits, which in-turn reduced weight loss (Debeaufort and Quezada-Galloand, 1998). Wrapping by guar or xanthan play a role in oxygen reduction within the wrapped sample, therefore can protect these characters, presumably through prevention of oxidation (Wong et al., 1994). The chitosan coating containing $1.0 \%$ of acetic acid lessened the weight loss in white and red prickly pears. However, both types of prickly pears treated with chitosan containing $2.5 \%$ of acetic acid showed the highest weight loss during storage. Experiments have indicated that the application of edible coatings to whole and minimally 
processed fruits and vegetables may prevent weight loss, according to OchoaVelasco and Guerrero-Beltrán (2014). Edible coatings reduced the weight loss because it has semi-permeable properties which lead to extend shelf life by reducing the moisture content (Bellaouchi et al., 2017).

Table (4): Effect of modified atmospheric packaging andedible coatings on weight loss of minimally processed prickly pear duringcoldstorageat $\left(4 \pm 1^{\circ} \mathrm{C}\right)$.

\begin{tabular}{|c|c|c|c|c|}
\hline \multirow{2}{*}{ Storage days } & \multicolumn{4}{|c|}{ Treatments } \\
\hline & $\mathrm{A}$ & $\mathrm{B}$ & $\mathrm{C}$ & $\mathrm{D}$ \\
\hline \multicolumn{5}{|c|}{ Season 2019} \\
\hline 3 & 1.65 & 1.50 & 1.32 & 1.25 \\
\hline 6 & 5.42 & 3.00 & 2.59 & 2.12 \\
\hline 9 & $\mathrm{R}$ & 4.12 & 3.45 & 3.23 \\
\hline 12 & $\mathrm{R}$ & 5.23 & 4.67 & 3.89 \\
\hline 15 & $\mathrm{R}$ & 5.10 & 4.89 & 4.33 \\
\hline 18 & $\mathrm{R}$ & $\mathrm{R}$ & 5.35 & 4.95 \\
\hline 21 & $\mathrm{R}$ & $\mathrm{R}$ & $\mathrm{R}$ & 5.45 \\
\hline LSD at $0.05 \%$ & \multicolumn{4}{|c|}{ Storage period $(S)=0.5441$ Treatments $(T)=0.6592 \quad S \& T=1.667$} \\
\hline \multicolumn{5}{|c|}{ Season 2020} \\
\hline 3 & 1.70 & 1.54 & 1.35 & 1.27 \\
\hline 6 & 5.45 & 3.11 & 2.63 & 2.45 \\
\hline 9 & $\mathrm{R}$ & 4.36 & 3.76 & 3.68 \\
\hline 12 & $\mathrm{R}$ & 5.43 & 4.87 & 3.93 \\
\hline 15 & $\mathrm{R}$ & 5.67 & 4.95 & 4.94 \\
\hline 18 & $\mathrm{R}$ & $\mathrm{R}$ & 5.72 & 5.12 \\
\hline 21 & $\mathrm{R}$ & $\mathrm{R}$ & $\mathrm{R}$ & 5.96 \\
\hline LSD at $0.05 \%$ & $\mathrm{~S}=0.5572$ & $\mathrm{~T}=0$ & $\& \mathrm{~T}=1$. & \\
\hline
\end{tabular}

$\mathrm{A}=$ Control, $\mathrm{B}=$ Under vacuum, $\mathrm{C}=$ Mixing, $60 \% \mathrm{CO}_{2} / 20 \% \mathrm{~N}_{2} / 20 \% \mathrm{O}_{2}, \mathrm{D}=$ Mixing, $60 \%$ $\mathrm{CO}_{2} / 20 \% \mathrm{~N}_{2} / 20 \% \mathrm{O}_{2}+$ Edible coating, $\mathrm{R}=$ rejected.

\subsubsection{Total soluble solids}

The results in Table (5) indicated that the total soluble solids (TSS) of minimally processed prickly pear was increased with increasing storage period, might due to the evaporation of water wrapping by gum which play a role in reduction within the wrapped sample, therefore can protect these characters, presumably through prevention of oxidation (Wong et al., 1994). Coating film on the surface of strawberry reduced respiration rate and vital process, thus reducing the loss of TSS during storage (Tanada-Palmu and Grosso, 2005). The interaction between treatments and storage period was not significant $(p \geq 0.05)$ in both seasons.

\subsubsection{Titratable acidity}

Data in the Table (6) showed that, the slight decrease in acidity of prickly pear fruits during storage period. A slow decrease in acidity may be due to natural variability among cultivars. These results are in agreement with those obtained by 
Barbera et al. (1992). However, the the changes in $\mathrm{pH}$, titratable acidity and decrease of acidity during storage effectively delaying fruit senescence demonstrated fruit senescence. The same (Abd El-Zaher, 2008; Bellaouchi et al., authors outlined that coatings may slow 2017).

Table (5): Effect of modified atmospheric packagingandedible coatings on total soluble solids of minimally processed prickly pear duringcold storageat $\left(4 \pm 1^{\circ} \mathrm{C}\right)$.

\begin{tabular}{|c|c|c|c|c|}
\hline \multirow{2}{*}{ Storage days } & \multicolumn{4}{|c|}{ Treatments } \\
\hline & A & B & $\mathrm{C}$ & D \\
\hline \multicolumn{5}{|c|}{ Season 2019} \\
\hline 3 & 10.45 & 10.50 & 10.60 & 10.75 \\
\hline 6 & 13.63 & 10.70 & 11.85 & 11.98 \\
\hline 9 & $\mathrm{R}$ & 12.95 & 11.20 & 12.35 \\
\hline 12 & $\mathrm{R}$ & 13.35 & 12.45 & 13.65 \\
\hline 15 & $\mathrm{R}$ & 14.58 & 13.85 & 14.87 \\
\hline 18 & $\mathrm{R}$ & $\mathrm{R}$ & 15.97 & 16.00 \\
\hline 21 & $\mathrm{R}$ & $\mathrm{R}$ & $\mathrm{R}$ & 17.55 \\
\hline \multirow{2}{*}{\multicolumn{5}{|c|}{$\begin{array}{cc}S=1.3442 \quad T=0.1677 & S \& T=0.2976 \\
\text { Season } 2020 & \end{array}$}} \\
\hline & & & & \\
\hline 3 & 10.42 & 10.64 & 10.65 & 10.79 \\
\hline 6 & 13.60 & 11.78 & 11.90 & 11.10 \\
\hline 9 & $\mathrm{R}$ & 12.98 & 12.35 & 12.45 \\
\hline 12 & $\mathrm{R}$ & 13.42 & 13.65 & 13.85 \\
\hline 15 & $\mathrm{R}$ & 14.67 & 14.90 & 14.14 \\
\hline 18 & $\mathrm{R}$ & $\mathrm{R}$ & 15.20 & 16.74 \\
\hline 21 & $\mathrm{R}$ & $\mathrm{R}$ & $\mathrm{R}$ & 17.95 \\
\hline LSD at $0.05 \%$ & \multicolumn{4}{|c|}{$\mathrm{S}=0.0265 \quad \mathrm{~T}=0.0278 \quad \mathrm{~S} \& \mathrm{~T}=0.564$} \\
\hline
\end{tabular}

$\mathrm{A}=$ Control, $\mathrm{B}=$ Under vacuum, $\mathrm{C}=$ Mixing, $60 \% \mathrm{CO}_{2} / 20 \% \mathrm{~N}_{2} / 20 \% \mathrm{O}_{2}, \mathrm{D}=$ Mixing, $60 \% \mathrm{CO}_{2} / 20 \% \mathrm{~N}_{2} / 20 \% \mathrm{O}_{2}+$ Edible coating, $\mathrm{R}=$ rejected. $\mathrm{S}=$ Storage pericd, $\mathrm{T}=$ Treatment, $\mathrm{S} \& \mathrm{~T}=$ Intefaction between treatments and storage period.

\subsubsection{Firmness}

Data in Table (7) revealed that firmness of prickly pear fruits was decreased during cold storage in both modified atmosphere packaging mixing, $\left(60 \% \mathrm{CO}_{2}\right.$ $120 \% \mathrm{~N}_{2} / 20 \% \mathrm{O}_{2}$ ) with edible coating (D) and mixing, $\left(60 \% \quad \mathrm{CO}_{2} / 20 \% \quad \mathrm{~N}_{2}\right.$ $\left.120 \% \mathrm{O}_{2}\right)(\mathrm{C})$ while, under vacuum have a clear significant different on firmness $(\mathrm{N})$ than that of control sample. Also, data in Table (4) revealed that prickly pear fruits before storage were firmness than the end of storage period. There was significant $(p \geq 0.05)$ reduction in fruit firmness loses during storage in all modified atmospheric packaging, edible coatings and under vacuum compared with the control sample. These results are in agreement with those obtained by Rodriguez et al. (1992). It could be responsible for delaying ripening which resulted in the reduction of firmness loss during storage. Tanada-Palmu and Grosso (2005) found that increasing of respiration activates with increasing of water loss and most likely decreased potential texture depression. 
Table (6): Effect of modified atmospheric packaging andedible coatings on titratable acidity $(\mathrm{g} / 100 \mathrm{~g})$ of minimally processed prickly pear during cold storage at $\left(4 \pm 1^{\circ} \mathrm{C}\right)$.

\begin{tabular}{|l|c|c|c|c|}
\hline \multirow{2}{*}{ Storage days } & \multicolumn{5}{|c|}{ Treatments } \\
\cline { 2 - 5 } & $\mathrm{A}$ & $\mathrm{B}$ & $\mathrm{C}$ & $\mathrm{D}$ \\
\hline \multicolumn{5}{|c|}{ Season 2019} \\
\hline 6 & 0.72 & 0.74 & 0.76 & 0.78 \\
\hline 9 & 0.46 & 0.68 & 0.71 & 0.73 \\
\hline 12 & $\mathrm{R}$ & 0.62 & 0.64 & 0.66 \\
\hline 15 & $\mathrm{R}$ & 0.47 & 0.50 & 0.54 \\
\hline 18 & $\mathrm{R}$ & 0.35 & 0.40 & 0.42 \\
\hline 21 & $\mathrm{R}$ & $\mathrm{R}$ & 0.36 & 0.38 \\
\hline LSD at $0.05 \%$ & $\mathrm{R}$ & $\mathrm{R}$ & $\mathrm{R}$ & 0.34 \\
\hline \multicolumn{5}{|c|}{$\mathrm{S}=0.0708 \mathrm{~T}=0.0765$} \\
\hline 3 & $\mathrm{~S} \& \mathrm{~T}=0.152$ \\
\hline 6 & 0.73 & 0.75 & 0.77 & 0.79 \\
\hline 9 & 0.47 & 0.69 & 0.73 & 0.75 \\
\hline 12 & $\mathrm{R}$ & 0.64 & 0.65 & 0.67 \\
\hline 15 & $\mathrm{R}$ & 0.50 & 0.52 & 0.54 \\
\hline 18 & $\mathrm{R}$ & 0.37 & 0.42 & 0.44 \\
\hline 21 & $\mathrm{R}$ & $\mathrm{R}$ & 0.37 & 0.39 \\
\hline LSD at $0.05 \%$ & $\mathrm{R}$ & $\mathrm{R}$ & $\mathrm{R}$ & 0.33 \\
\hline
\end{tabular}

$\mathrm{A}=$ Control, $\mathrm{B}=$ Under vacuum, $\mathrm{C}=$ Mixing, $60 \% \mathrm{CO}_{2} / 20 \% \mathrm{~N}_{2} / 20 \% \mathrm{O}_{2}, \mathrm{D}=$ Mixing, $60 \% \mathrm{CO}_{2} / 20 \% \mathrm{~N}_{2} / 20 \% \mathrm{O}_{2}+$ Edible coating, $\mathrm{R}=$ rejected. $\mathrm{S}=$ Storage pericd, $\mathrm{T}=$ Treatment, $\mathrm{S} \& \mathrm{~T}=$ Intefaction between treatments and storage period.

Table (7): Effect of modified atmospheric packaging andedible coatings on firmness $(\mathrm{N})$ of minimally processed prickly pear duringcoldstorageat $\left(4 \pm 1^{\circ} \mathrm{C}\right)$.

\begin{tabular}{|c|c|c|c|c|}
\hline \multirow{2}{*}{ Storage days } & \multicolumn{4}{|c|}{ Treatments } \\
\hline & A & $\mathrm{B}$ & $\mathrm{C}$ & $\mathrm{D}$ \\
\hline \multicolumn{5}{|c|}{ Season 2019} \\
\hline 3 & 62.15 & 64.32 & 66.16 & 68.54 \\
\hline 6 & 56.56 & 62.10 & 64.56 & 66.56 \\
\hline 9 & $\mathrm{R}$ & 59.65 & 62.00 & 64.65 \\
\hline 12 & $\mathrm{R}$ & 57.45 & 60.45 & 62.67 \\
\hline 15 & $\mathrm{R}$ & 55.34 & 58.56 & 60.78 \\
\hline 18 & $\mathrm{R}$ & $\mathrm{R}$ & 56.43 & 58.65 \\
\hline 21 & $\mathrm{R}$ & $\mathrm{R}$ & $\mathrm{R}$ & 56.45 \\
\hline LSD at $0.05 \%$ & \multicolumn{4}{|c|}{$\mathrm{S}=3.925 \quad \mathrm{~T}=4.384 \quad \mathrm{~S} \& \mathrm{~T}=7.634$} \\
\hline \multicolumn{5}{|c|}{ Season 2020} \\
\hline 3 & 61.00 & 63.23 & 64.68 & 66.78 \\
\hline 6 & 54.56 & 61.56 & 62.78 & 64.45 \\
\hline 9 & $\mathrm{R}$ & 59.56 & 60.67 & 62.84 \\
\hline 12 & $\mathrm{R}$ & 57.58 & 58.75 & 60.89 \\
\hline 15 & $\mathrm{R}$ & 55.65 & 56.46 & 59.10 \\
\hline 18 & $\mathrm{R}$ & $\mathrm{R}$ & 54.67 & 57.65 \\
\hline 21 & $\mathrm{R}$ & $\mathrm{R}$ & $\mathrm{R}$ & 55.47 \\
\hline LSD at $0.05 \%$ & \multicolumn{4}{|c|}{$\mathrm{S}=2.845 \quad \mathrm{~T}=3.452 \quad \mathrm{~S} \& \mathrm{~T}=5.862$} \\
\hline
\end{tabular}

$\mathrm{A}=$ Control, $\mathrm{B}=$ Under vacuum, $\mathrm{C}=$ Mixing, $60 \% \mathrm{CO}_{2} / 20 \% \mathrm{~N}_{2} / 20 \% \mathrm{O}_{2}, \mathrm{D}=$ Mixing, $60 \% \mathrm{CO}_{2} / 20 \% \mathrm{~N}_{2} / 20 \% \mathrm{O}_{2}+$ Edible coating, $\mathrm{R}=$ rejected. $\mathrm{S}=$ Storage pericd, $\mathrm{T}=$ Treatment, $\mathrm{S} \& \mathrm{~T}=$ Intefaction between treatments and storage period. 


\subsubsection{Total carotenoids}

The obtained results in Table (8) showed that the carotene was increased with increasing the storage period. It was also observed that treatment with gases preserved carotene, which led to an increase in the percentage of carotene, followed by edible coating (gases) and vacuum as compared to the control, where it decreased. de Figueiredo et al. (2002) reported that the increasing of carotenoids during refrigerator storage due to chlorophyll degradation and converted its carotenoids at minimized rate.

Table (8): Effect of modified atmospheric packaging andedible coatings on total carotenoids of prickly pear during cold storage at $\left(4 \pm 1^{\circ} \mathrm{C}\right)$.

\begin{tabular}{|c|c|c|c|c|}
\hline \multirow{2}{*}{ Storage days } & \multicolumn{4}{|c|}{ Treatments } \\
\hline & $\mathrm{A}$ & B & $\mathrm{C}$ & $\mathrm{D}$ \\
\hline \multicolumn{5}{|c|}{ Season 2019} \\
\hline 3 & 11.70 & 12.45 & 13.25 & 14.46 \\
\hline 6 & 11.95 & 12.88 & 13.70 & 14.68 \\
\hline 9 & $\mathrm{R}$ & 13.35 & 13.95 & 14.95 \\
\hline 12 & $\mathrm{R}$ & 13.90 & 14.00 & 15.25 \\
\hline 15 & $\mathrm{R}$ & 14.45 & 14.25 & 15.55 \\
\hline 18 & $\mathrm{R}$ & $\mathrm{R}$ & 14.56 & 15.89 \\
\hline 21 & $\mathrm{R}$ & $\mathrm{R}$ & $\mathrm{R}$ & 15.95 \\
\hline \multirow{2}{*}{\multicolumn{5}{|c|}{$\begin{array}{c}S=0.135 \quad T=0.0126 \\
\text { Season } 2020\end{array}$}} \\
\hline & & & & \\
\hline 3 & 11.20 & 12.10 & 13.12 & 14.21 \\
\hline 6 & 11.56 & 12.45 & 13.24 & 14.56 \\
\hline 9 & $\mathrm{R}$ & 12.85 & 13.65 & 14.89 \\
\hline 12 & $\mathrm{R}$ & 13.24 & 13.94 & 14.97 \\
\hline 15 & $\mathrm{R}$ & 13.60 & 14.19 & 15.23 \\
\hline 18 & $\mathrm{R}$ & $\mathrm{R}$ & 14.45 & 15.39 \\
\hline 21 & $\mathrm{R}$ & $\mathrm{R}$ & $\mathrm{R}$ & 15.45 \\
\hline LSD at $0.05 \%$ & \multicolumn{4}{|c|}{$\begin{array}{lll}\mathrm{S}=0.01562 & \mathrm{~T}=0.0184 & \mathrm{~S} \& \mathrm{~T}=0.0438\end{array}$} \\
\hline
\end{tabular}

3.3 Total bacterial count, psychrophilic bacterial count and moulds and yeasts

The results indicated in the Table $(9,10$, 11) show that microbial total count, psychrophilic bacterial count and moulds and yeasts growth were increased with increasing the storage period. However, modified atmospheric packaging, edible coating and under vacuum treatment was the most effective treatments for reducing total microbial, psychrophilic bacterial count and moulds and yeasts counts, without significant $(\mathrm{p} \leq 0.05)$ differences between the two modified atmospheric packaging and edible coatings treatments. Microbe populations were unchanged in white prickly pears $\left(10 \mathrm{CFU} \times 10^{-1} / \mathrm{g}\right)$ and slightly increased in red prickly pears $\left(10-500 \mathrm{CFU} \times 10^{-}\right.$ $1 / \mathrm{g}$ ) coated with chitosan during the entire storage time, according to Ochoa- 
Velasco and Guerrero-Beltrán (2014). The chitosan coatings lessened the population growth of aerobic mesophiles during the entire storage time. Both cultivars of prickly pear never reached the maximum amount $\left(1500 \mathrm{CFU} \times 10^{-1} /\right.$ g) permitted Official Norm NOM-093SSA1-1994 (1994). Yeast and mold populations on the controls were below detection at 0 and $4 \mathrm{~d}$, and increased to 30.44 and $50 \mathrm{CFU} \times 10^{-1} / \mathrm{g}$ after 8,12 , and 16 day, respectively. Among those treated with chitosan coatings yeast plus mold populations were below detectable levels except they were 15 after 16 day in treatment with chitosan in $1.0 \%$ of acetic acid. With red prickly pears, yeast plus mold populations on the controls were below detection after 0,4 , and 8 day and increased to 43 and $65 \mathrm{CFU} \mathrm{x} 10^{-1} / \mathrm{g}$ after 12 and $16 \mathrm{~d}$ of storage, respectively (Chien et al., 2007).

Table (9): Effect of modified atmospheric packaging andedible coatings on total bacterial count $\left(\mathrm{CFU} \times 10^{-1} / \mathrm{g}\right)$ of prickly pear during cold storage at $\left(4 \pm 1^{\circ} \mathrm{C}\right)$.

\begin{tabular}{|c|c|c|c|c|}
\hline \multirow{2}{*}{ Storage days } & \multicolumn{4}{|c|}{ Treatments } \\
\hline & $\mathrm{A}$ & B & $\mathrm{C}$ & $\mathrm{D}$ \\
\hline \multicolumn{5}{|c|}{ Season 2019} \\
\hline 3 & 2.75 & 2.75 & 2.75 & 2.75 \\
\hline 6 & 5.89 & 3.95 & 3.23 & 3.00 \\
\hline 9 & 12.26 & 5.82 & 4.54 & 3.75 \\
\hline 12 & $\mathrm{R}$ & 8.45 & 7.87 & 6.45 \\
\hline 15 & $\mathrm{R}$ & 11.57 & 10.54 & 9.82 \\
\hline 18 & $\mathrm{R}$ & 12.65 & 10.82 & 10.13 \\
\hline 21 & $\mathrm{R}$ & $\mathrm{R}$ & 11.43 & 11.12 \\
\hline LSD at $0.05 \%$ & \multicolumn{4}{|c|}{$\begin{array}{lll}\mathrm{S}=0.587 & \mathrm{~T}=0.243 & \mathrm{~S} \& \mathrm{~T}=0.126 \\
\end{array}$} \\
\hline \multicolumn{5}{|c|}{ Season 2020} \\
\hline 3 & 2.80 & 2.80 & 2.80 & 2.80 \\
\hline 6 & 5.98 & 3.97 & 3.45 & 3.42 \\
\hline 9 & 13.50 & 5.90 & 4.67 & 3.95 \\
\hline 12 & $\mathrm{R}$ & 8.75 & 7.95 & 6.65 \\
\hline 15 & $\mathrm{R}$ & 11.78 & 10.78 & 9.90 \\
\hline 18 & $\mathrm{R}$ & 12.95 & 11.00 & 10.24 \\
\hline 21 & $\mathrm{R}$ & $\mathrm{R}$ & 11.65 & 11.45 \\
\hline LSD at $0.05 \%$ & \multicolumn{4}{|c|}{$\mathrm{S}=0.642 \quad \mathrm{~T}=0.0563 \quad \mathrm{~S} \& \mathrm{~T}=0.0942$} \\
\hline
\end{tabular}

\subsection{Total colony count}

The results pointed out that all prickly pears were free from coliform group bacteria which may be due to the good sanitation practices in preparation and packaging of prickly pear, that could reduce the load of pathogenic microorganisms as reported by Pirovani et al. (1996), Increasing the chitosan in the emulsion to form the coating of chitosan may reduce microbial growth during storage. Sholberg et al. (2000) reported that increasing the amount of vinegar (vapor) during cutting as a postharvest treatment significantly 
decreased the development of conidia of Bacillus cinerea in fruits.

Table (10): Effect of modified atmospheric packaging andedible coatings on psychrophilic bacterial count $\left(\mathrm{CFU} \times 10^{-1} / \mathrm{g}\right)$ of prickly pear during coldstorageat $\left(4 \pm 1^{\circ} \mathrm{C}\right)$.

\begin{tabular}{|c|c|c|c|c|}
\hline \multirow{2}{*}{ Storage days } & \multicolumn{4}{|c|}{ Treatments } \\
\hline & A & B & $\mathrm{C}$ & $\mathrm{D}$ \\
\hline \multicolumn{5}{|c|}{ Season 2019} \\
\hline 3 & 2.70 & 2.70 & 2.70 & 2.70 \\
\hline 6 & 5.81 & 3.90 & 3.19 & 2.90 \\
\hline 9 & 11.26 & 4.83 & 3.56 & 3.00 \\
\hline 12 & $\mathrm{R}$ & 6.40 & 5.84 & 4.43 \\
\hline 15 & $\mathrm{R}$ & 10.55 & 9.54 & 8.88 \\
\hline 18 & $\mathrm{R}$ & 11.65 & 10.82 & 10.13 \\
\hline 21 & $\mathrm{R}$ & $\mathrm{R}$ & 11.43 & 11.33 \\
\hline \multirow{2}{*}{\multicolumn{5}{|c|}{$\begin{array}{cc}S=0.0045 \quad T=0.0063 & S \& T=0.0052 \\
\text { Season } 2020 & \end{array}$}} \\
\hline & & & & \\
\hline 3 & 2.76 & 2.76 & 2.76 & 2.76 \\
\hline 6 & 5.98 & 3.94 & 3.45 & 3.33 \\
\hline 9 & 11.40 & 5.70 & 476 & 3.88 \\
\hline 12 & $\mathrm{R}$ & 8.82 & 7.59 & 6.45 \\
\hline 15 & $\mathrm{R}$ & 11.66 & 10.54 & 9.87 \\
\hline 18 & $\mathrm{R}$ & 12.90 & 11.20 & 10.64 \\
\hline 21 & $\mathrm{R}$ & $\mathrm{R}$ & 11.74 & 1150 \\
\hline LSD at $0.05 \%$ & \multicolumn{4}{|c|}{$\mathrm{S}=0.0034 \quad \mathrm{~T}=0.0024 \quad \mathrm{~S} \& \mathrm{~T}=0.0032$} \\
\hline
\end{tabular}

$\mathrm{A}=$ Control, $\mathrm{B}=$ Under vacuum, $\mathrm{C}=$ Mixing, $60 \% \mathrm{CO}_{2} / 20 \% \mathrm{~N}_{2} / 20 \% \mathrm{O}_{2}, \mathrm{D}=$ Mixing, $60 \% \mathrm{CO}_{2} / 20 \% \mathrm{~N}_{2} / 20 \% \mathrm{O}_{2}+$ Edible coating, $\mathrm{R}=$ rejected. $\mathrm{S}=$ Storage pericd, $\mathrm{T}=$ Treatment, $\mathrm{S} \& \mathrm{~T}=$ Intefaction between treatments and storage period.

Table (11): Effect of modified atmospheric packaging andedible coatings on moulds and yeasts count $\left(\mathrm{CFU} \times 10^{-1} \% \mathrm{~g}\right)$ of prickly pear during cold storage at $\left(4 \pm 1^{\circ} \mathrm{C}\right)$.

\begin{tabular}{|c|c|c|c|c|}
\hline \multirow{2}{*}{ Storage days } & \multicolumn{4}{|c|}{ Treatments } \\
\hline & $\mathrm{A}$ & B & $\mathrm{C}$ & $\mathrm{D}$ \\
\hline \multicolumn{5}{|c|}{ Season 2019} \\
\hline 3 & 0.75 & 0.75 & 0.75 & 0.75 \\
\hline 6 & 3.23 & 2.10 & 1.90 & 1.85 \\
\hline 9 & 4.68 & 3.32 & 2.25 & 2.12 \\
\hline 12 & $\mathrm{R}$ & 3.85 & 2.85 & 2.65 \\
\hline 15 & $\mathrm{R}$ & 4.10 & 3.45 & 3.23 \\
\hline 18 & $\mathrm{R}$ & 4.56 & 3.88 & 3.65 \\
\hline 21 & $\mathrm{R}$ & $\mathrm{R}$ & 4.00 & 3.89 \\
\hline LSD at $0.05 \%$ & & $\mathrm{~T}$ & S\& & \\
\hline \multicolumn{5}{|c|}{$\begin{array}{c}\mathrm{S}=0.0432 \quad \mathrm{~T}=0.0523 \\
\text { Season } 2020\end{array}$} \\
\hline 3 & 0.80 & 0.80 & 0.80 & 0.80 \\
\hline 6 & 3.34 & 2.28 & 2.00 & 1.95 \\
\hline 9 & 4.85 & 3.96 & 2.54 & 2.35 \\
\hline 12 & $\mathrm{R}$ & 4.10 & 2.95 & 2.86 \\
\hline 15 & $\mathrm{R}$ & 4.28 & 3.58 & 3.35 \\
\hline 18 & $\mathrm{R}$ & 4.65 & 3.98 & 3.90 \\
\hline 21 & $\mathrm{R}$ & $\mathrm{R}$ & 4.12 & 3.95 \\
\hline LSD at $0.05 \%$ & \multicolumn{4}{|c|}{$\begin{array}{lll}\mathrm{S}=0.0543 & \mathrm{~T}=0.0423 & \mathrm{~S} \& \mathrm{~T}=0.0653\end{array}$} \\
\hline
\end{tabular}

$\mathrm{A}=$ Control, $\mathrm{B}=$ Under vacuum, $\mathrm{C}=$ Mixing, $60 \% \mathrm{CO}_{2} / 20 \% \mathrm{~N}_{2} / 20 \% \mathrm{O}_{2}, \mathrm{D}=$ Mixing, $60 \% \mathrm{CO}_{2} / 20 \% \mathrm{~N}_{2} / 20 \% \mathrm{O}_{2}+$ Edible coating, $\mathrm{R}=$ rejected. $\mathrm{S}=$ Storage pericd, $\mathrm{T}=$ Treatment, $\mathrm{S} \& \mathrm{~T}=$ Intefaction between treatments and storage period. 


\subsection{Sensory evaluation}

Statistical analysis of panelists scores of organoleptic properties of the modified atmospheric packaging and edible coatings of minimally processed prickly pear during cold storage. Data in Table (12) revealed a gradually significant $(p \geq 0.05)$ decreased in values of the flavor, color, appearance and overall acceptability with increasing the storage period (21 days) for treatment mixing, $\left(60 \% \mathrm{CO}_{2} / 20 \% \mathrm{~N}_{2} / 20 \% \mathrm{O}_{2}\right)$ with edible coating (D). Generally, it could be concluded that modified atmospheric packaging and edible coatings of minimally processed prickly pear prolonged its shelf life, freshness and quality upon cold storage. However, the storage in the modified atmospheric packaging and edible coating minimally processed prickly pear at cold temperature more effective than control sample.

Table (12): Sensory evaluation of prickly pear duringcoldstorage at $\left(4 \pm 1^{\circ} \mathrm{C}\right)$.

\begin{tabular}{|c|c|c|c|c|c|c|c|c|c|c|c|c|c|c|c|c|}
\hline \multirow{4}{*}{$\begin{array}{l}\text { Storage } \\
\text { days }\end{array}$} & \multicolumn{16}{|c|}{ Treatments } \\
\hline & \multicolumn{4}{|c|}{$\mathrm{A}$} & \multicolumn{4}{|c|}{$\mathrm{B}$} & \multicolumn{4}{|c|}{$\mathrm{C}$} & \multicolumn{4}{|c|}{$\mathrm{D}$} \\
\hline & $\mathrm{F}$ & $\mathrm{L}$ & $\mathrm{P}$ & $\mathrm{O}$ & $\mathrm{F}$ & $\mathrm{L}$ & $\mathrm{P}$ & $\mathrm{O}$ & $\mathrm{F}$ & $\mathrm{L}$ & $\mathrm{P}$ & $\mathrm{O}$ & $\mathrm{F}$ & $\mathrm{L}$ & $\mathrm{P}$ & $\mathrm{O}$ \\
\hline & \multicolumn{16}{|c|}{ Season (2019) } \\
\hline 0 & 24.99 & 7.75 & 46.50 & 79.24 & 25.65 & 8.15 & 48.60 & 82.4 & 24.6 & 7.30 & 48.6 & 80.5 & 25.05 & 7.10 & 49.2 & 81.35 \\
\hline 3 & 19.05 & 7.80 & 36.00 & 62.85 & 22.2 & 8.43 & 46.5 & 77.13 & 24.00 & 7.45 & 48.00 & 79.45 & 24.36 & 7.45 & 48.00 & 79.81 \\
\hline 6 & 12.3 & 7.90 & 24.00 & 44.2 & 20.16 & 8.75 & 42.9 & 71.81 & 23.1 & 7.60 & 47.4 & 78.1 & 23.35 & 7.75 & 47.8 & 78.9 \\
\hline 9 & $\mathrm{R}$ & $\mathrm{R}$ & $\mathrm{R}$ & $\mathrm{R}$ & 18.00 & 8.90 & 42.00 & 68.9 & 20.7 & 7.80 & 46.5 & 75 & 21.45 & 7.85 & 47.00 & 76.3 \\
\hline 12 & $\mathrm{R}$ & $\mathrm{R}$ & $\mathrm{R}$ & $\mathrm{R}$ & 15.3 & 9.00 & 39.60 & 63.9 & 20.2 & 8.0 & \begin{tabular}{|l|l}
44.4 \\
\end{tabular} & 72.6 & 20.1 & 8.10 & 45.5 & 73.7 \\
\hline 15 & $\mathrm{R}$ & $\mathrm{R}$ & $\mathrm{R}$ & $\mathrm{R}$ & 14.1 & $9 . .0$ & 29.1 & 52.2 & 17.55 & 8.10 & 36.6 & 62.25 & 19.2 & 8.20 & 41.4 & 68.8 \\
\hline 18 & $\mathrm{R}$ & $\mathrm{R}$ & $\mathrm{R}$ & $\mathrm{R}$ & $\mathrm{R}$ & $\mathrm{R}$ & $\mathrm{R}$ & $\mathrm{R}$ & 15.00 & 8.12 & 28.15 & 51.27 & 15.9 & 8.33 & 39.6 & 63.83 \\
\hline 21 & $\mathrm{R}$ & $\mathrm{R}$ & $\mathrm{R}$ & $\mathrm{R}$ & $\mathrm{R}$ & $\mathrm{R}$ & $\mathrm{R}$ & $\mathrm{R}$ & $\mathrm{R}$ & $\mathrm{R}$ & $\mathrm{R}$ & $\mathrm{R}$ & 15.00 & 8.33 & 29.00 & 52.33 \\
\hline \multicolumn{17}{|c|}{ LSD at $0.05 \%$} \\
\hline \multicolumn{17}{|c|}{ Season (2020) } \\
\hline 0 & 25.50 & 7.80 & 48.01 & 81.31 & 30.30 & 8.00 & 49.11 & 87.41 & 28.44 & 7.33 & 50.00 & 85.77 & 29.40 & 7.50 & 50.37 & 87.27 \\
\hline 3 & 18.90 & 7.90 & 36.55 & 63.35 & 26.65 & 8.20 & 46.43 & 81.28 & 26.34 & \begin{tabular}{|l|}
7.55 \\
\end{tabular} & 48.22 & 82.11 & 27.45 & 7.75 & 48.75 & 83.95 \\
\hline 6 & 11.10 & 8.00 & 23.16 & 42.26 & 23.10 & 8.50 & 43.00 & 74.60 & 24.31 & 7.75 & 47.10 & 79.16 & 26.63 & 7.88 & 48.55 & 83.06 \\
\hline 9 & $\mathrm{R}$ & $\mathrm{R}$ & $\mathrm{R}$ & $\mathrm{R}$ & 20.00 & 8.75 & 42.15 & 70.90 & 22.09 & 7.88 & 46.50 & 76.47 & 24.60 & 7,95 & 46.45 & 79.00 \\
\hline 12 & $\mathrm{R}$ & $\mathrm{R}$ & $\mathrm{R}$ & $\mathrm{R}$ & 16.25 & 8.90 & 38.90 & 64.05 & 18.00 & \begin{tabular}{|l|}
7.95 \\
\end{tabular} & 43.55 & 69.50 & 22.00 & 8.05 & 45.00 & 75.05 \\
\hline 15 & $\begin{array}{l}\mathrm{R} \\
\end{array}$ & $\mathrm{R}$ & R & \begin{tabular}{|l}
$\mathrm{R}$ \\
\end{tabular} & 13.22 & 9.01 & 28.85 & 51.08 & 16.33 & 8.10 & \begin{tabular}{|l|}
37.02 \\
\end{tabular} & 61.45 & 19.75 & 8.15 & 40.85 & 68.75 \\
\hline 18 & $\mathrm{R}$ & $\mathrm{R}$ & $\mathrm{R}$ & $\mathrm{R}$ & $\mathrm{R}$ & $\mathrm{R}$ & $\mathrm{R}$ & $\mathrm{R}$ & 14.18 & 8.15 & 28.00 & 50.33 & 17.55 & 8.25 & 38.00 & 63.80 \\
\hline 21 & $\mathrm{R}$ & $\mathrm{R}$ & $\mathrm{R}$ & $\mathrm{R}$ & $\mathrm{R}$ & $\mathrm{R}$ & $\mathrm{R}$ & $\mathrm{R}$ & $\mathrm{R}$ & $\mathrm{R}$ & $\mathrm{R}$ & $\mathrm{R}$ & 14.90 & 8.30 & 28.90 & 52.10 \\
\hline \multicolumn{17}{|c|}{ LSD at $0.05 \% \quad \mathrm{~S}=4.3726$} \\
\hline
\end{tabular}

$\mathrm{A}=$ Control, $\mathrm{B}=$ Under vacuum, $\mathrm{C}=$ Mixing, $60 \% \mathrm{CO}_{2} / 20 \% \mathrm{~N}_{2} / 20 \% \mathrm{O}_{2}, \mathrm{D}=$ Mixing, $60 \% \mathrm{CO}_{2} / 20 \% \mathrm{~N}_{2} / 20 \% \mathrm{O}_{2}+$ Edible coating, $\mathrm{F}=$ Flavor (30), $\mathrm{L}=$ Color (10), $\mathrm{P}=$ Appearance (60), $\mathrm{O}=$ Over all acceptability, $\mathrm{R}=$ Rejected samples, $\mathrm{S}=$ Storage pericd, $\mathrm{T}=$ Treatment, $\mathrm{S} \& \mathrm{~T}=$ Intefaction between treatments and storage period.

Finally, the obtained results in this study it could be concluded that these findings may be of application benefit in the field of food industry. Organoleptic properties of the product can be assessed by color, flavor and texture (Özogul and Özogul, 2006). Statistical comparisons between the results from sensory changes during the storage period showed that there were significant $\quad(p \geq 0.05)$ differences in reducing values depended on the storage period. In addition, it was found that the statistical importance between the values of appearance, odor, flavor and texture were higher than in the other months in the samples of vacuum packaging, and 
gas mixtures $\left(70 \% \mathrm{CO}_{2} / 30 \% \quad \mathrm{~N}_{2}, 50 \%\right.$

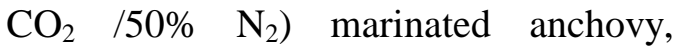
respectively (Günşen et al., 2011). This phenomenon causes changes in organoleptic properties of the product, where high percentage of $\mathrm{CO}_{2}$ probably leads to negative effects on other aspects of the product especially on the sensory aspects. Efficiency of carbon dioxide as anti-microorganism mediator is not entire and is relies on the food product properties and the existence of microbial flora (Velu et al., 2013).

\section{Conclusion}

From the results, it became clear that modified atmospheric packaging with edible coating was the best, followed by modified atmospheric packaging alone, which prolonged the shelf life and enhanced the characteristics of prickly pear fruits quality when stored at the cold temperature compared with control. Based on obtained results in this study, it can be concluded that these results may be used in the food industries.

\section{References}

Abd El-Zaher, M. H. (2008), "Studies on seedless fruits (stoneless) of date palm cv. Barhee: effect of spraying with some natural materials on pollinated fruits, unpollinated fruits and properties of the fruit set", Journal of Applied Sciences Research,, Vol. 4 No. 7, pp. 906916.
AOAC (2010), Official methods of analysis association of official Agricultural chemists, $17^{\text {th }}$ Edition, The Association of Official Analytical Chemists, Washington, D.C., USA.

APHA (1992), Compendium methods microbiological examination foods, American Public Health Association, Washington. USA.

Artés, F., Gómez, P. A. and ArtésHernández, F. (2007), "Physical, physiological and microbial deterioration of minimally fresh processed fruits and vegetables", Food Science and Technology International, Vol. 13 No. 3, pp. 177-188.

Askar, A. and Treptow, H. (1993), "Sensory Analysis", In: Quality Assurance in Tropical Fruit Processing, Springer Laboratory, Springer, Heidelberg, Berlin, Germany.

Barbera, G., Carimi, F., Inglese, P., and Panno, M. (1992), "Physical, morphological and chemical changes during fruit development and ripening in three cultivars of prickly pear, Opuntia ficus-indica (L.) Miller", Journal of Horticultural Science, Vol. 67 No. 3, pp. 307-312.

Bellaouchi, R., Ghomari, I., Hasnaoui, A., Hakkou, A., Bechchari, A., Chihib, N. E. and Asehraou, A. (2017), "Physico-chemical and microbial properties of undervalued 
dates and processed dates byproducts in Morocco", International Food Research Journal, Vol. 24 No. 3, pp. 9636-969.

Belviranl, B., Al-Juhaimi, F., Özcan, M. M., Ghafoor, K., Babiker, E. E. and Alsawmahi, O. N. (2019), "Effect of location on some physico-chemical properties of prickly pear (Opuntia ficus-indica L.) fruit and seeds", Journal of Food Processing and Preservation, Vol. 43 No. 3, pp 138-150.

Bourne, M. C. (2003), Food texture and viscosity: concept and measurement, Elsevier Press, New York /London.

Bravin, B., Peressini, D. and Sensidoni, A. (2006), "Development and application of polysaccharide-lipid edible coating to extend shelf-life of dry bakery products", Journal of Food Engineering, Vol. 76 No. 3, pp. 280-290.

Chafer, M., Perez, S., Vargas, M. and Chiralt, A. (2008), "Stability and quality of minimally processed orange slices", Journal of Food Processing and Preservation, Vol. 32 No. 2, pp 319-334.

Chien, P. J., Sheu, F., and Yang, F. H. (2007), " Effects of edible chitosan coating on quality and shelf life of sliced mango fruit", Journal of Food Engineering, Vol. 78 No. 1, pp. 225-229.

Contreras-Calderón, J., Calderón-Jaimes, L., Guerra-Hernández, E. and
García-Villanova, B. (2011), "Antioxidant capacity, phenolic content and vitamin $\mathrm{C}$ in pulp, peel and seed from 24 exotic fruits from Colombia", Food Research International, Vol. 44 No. 7, pp. 2047-2053.

Cota-Sánchez, J. H. (2015), "Nutritional composition of the prickly pear (Opuntia ficus-indica) fruit", In: Nutritional Composition of Fruit Cultivars, Academic Press, Elsevier, pp. 691-712.

de Figueiredo, R. W., Lajolo, F. M., Alves, R. E. and Filgueiras, H. A. C. (2002), "Physical-chemical changes in early dwarf cashew pseudofruits during development and maturation", Food chemistry, Vol. 77 No. 3, pp. 343-347.

Debeaufort, F., Quezada-Gallo, J. A. and Voilley, A. (1998), "Edible films and coatings: tomorrow's packagings: a review", Critical Reviews in Food Science, Vol. 38 No. 4, pp. 299-313.

Deka, D. D., Patil, G. R. and Rajor, R. B. (1982), "Studies on the formulation of Lassi (cultured drink) from soybean and buttermilk", Egyptian Journal of Dairy Science, Vol. 21, pp. 291.

Djeridane, A., Yousfi, M., Nadjemi, B., Boutassouna, D., Stocker, P. and Vidal, N. (2006), "Antioxidant activity of some Algerian medicinal plants extracts containing phenolic compounds", Food Chemistry, Vol. 
97 No. 4, pp. 654-660.

Donhowe, I. G. and Fennema, O. (1994), "Edible films and coatings Characteristics, formation, definitions, and testing methods", In: Krochta J. M., Baldwin E. A., Nisperos-Carriedo M. O. (Eds.), Edible coatings and films to improve food quality, Technomic Publishing Co., Inc, Lancaster, Pennsylvania, USA, pp. pp1-24.

Elfalleh, W., Nasri, N., Marzougui, N., Thabti, I., M'rabet, A., Yahya, Y., Lachiheb, B., Guasmi, F. and Ferchichi, A. (2009), "Physicochemical properties and DPPHABTS scavenging activity of some local pomegranate (Punica granatum) ecotypes", International Journal of Food Sciences and Nutrition, Vol. 60 No. 2, pp. 197210.

Gissler, C. and Powers, H. (2010), Human Nutrition, 12 ${ }^{\text {ed }}$, Elsevier Amesterdam, The Netherlands.

Guassmi, F. and Ferchichi, A.(2009), "Physico-chemical properties and DPPH-ABTS scavenging activity of some local pomegranate (Punica granatum) ecotypes", International Journal of Food Sciences and Nutrition, Vol. 60 No. 2, pp. 197210.

Günşen, U., Özcan, A. and Aydın, A. (2011), "Determination of some quality criteria of cold storaged marinated anchovy under vacuum and modified atmosphere conditions", Turkish Journal of Fisheries and Aquatic Sciences, Vol. 11, pp. 233-242.

Han, C., Zhao, Y., Leonard, S. W. and Traber, M. G. (2004), "Edible coatings to improve storability and enhance nutritional value of fresh and frozen strawberries (Fragaria $x$ ananassa) and raspberries (Rubus ideaus)", Postharvest Biology and Technology, Vol. 33 No. 1, pp. 6778.

Hunt, M. C. and Mohan, A. (2008), Advancement in Meat Packaging, Sept $18-20^{\text {th }}$, Canadian Meat Council, Canada.

Ivanova, V., Stefova, M. and Chinnici, F. (2010), "Determination of the polyphenol contents in Macedonian grapes and wines by standardized spectrophotometric

methods", Journal of the Serbian Chemical Society, Vol. 75 No. 1, pp. 45-59.

Jambi Hanan, A. (2017), "Physiochemical, microbiological and sensory properties of probiotics prickly pear permeate beverages", Sciences, Vol. 7 No. 4, pp. 745-754.

Kähkönen, M. P., Hopia, A. I., Vuorela, H. J., Rauha, J. P., Pihlaja, K., Kujala, T. S. and Heinonen, M. (1999), "Antioxidant activity of plant extracts containing phenolic compounds", Journal of Agricultural and Food Chemistry, Vol. 47 No. 10, pp. 3954-3962. 
Kaleemullah, S. (2002), Food Packaging Study Material, Department of Food Engineering, College of Food Science and Technology, Pulivendula, India, pp. 516390.

Konopacka, D. and Plocharski, W. J. (2004), "Effect of storage conditions on the relationship between apple firmness and texture acceptability", Postharvest Biology and Technology, Vol. 32 No. 2, pp. 205-211.

Masniyom, P. (2011), "Deterioration and shelf-life extension of fish and fishery products by modified atmosphere

packaging", Songklanakarin Journal of Science \& Technology, Vol. 33 No. 2, pp. 181-192.

NOM-093-SSA1 (1994), Bienes y servicios. Practicas de higiene $y$ sanidad en la preparacion de alimentos que se ofrecen en establecimientos fijos, avilable at http://www.salud.gob.mx/unidades/c di/nom/093ssa14.html (update March, 2012).

Nussinovitch, A. (1997), Hydrocolloid applications: Gum technology in the food and other industries, Blackie Academic \& Professional, London, England, pp. 134-137.

Nussinovitch, A. (2000), "Gums for coatings and adhesives", Handbook of hydrocolloids, Woodhead Publishing, Cambridge, England, pp. 347-366.

Ochoa, C. E. and Guerrero, J. A. (2012),
"Efecto del almacenamiento a diferentes temperaturas sobre la calidad de tuna roja (Opuntia ficus indica (L.) Miller)". Información tecnológica, Vol. 23 No. 1, pp. 117128.

Ochoa-Velasco, C. E. and GuerreroBeltrán, J. (2014), "Postharvest quality of peeled prickly pear fruit treated with acetic acid and chitosan", Postharvest Biology and Technology, Vol. 92, pp 139-145.

Osman, K. I. (2011), "The behaviour of some vegetable-based materials used as edible coating on chicken nuggets", Food Technology and Biotechnology, Vol. 49 No. 2, pp. 237-243.

Özogul, F. and Özogul, Y. (2006), "Biogenic amine content and biogenic amine quality indices of sardines (Sardina pilchardus) stored in modified atmosphere packaging and vacuum packaging", Food Chemistry, Vol. 99 No. 3, pp. 574578.

Piga, A., D'Aquino, S., Agabbio, M., Emonti, G. and Farris, G. A. (2000), "Influence of storage temperature on shelf-life of minimally processed cactus pear fruits", LWT-Food Science and Technology, Vol. 3 No. 1, pp. 15-20.

Pirovani, M. E., Güemes, D. R., Piagentini, A. M. and Di Pentima, J. H. (1996), "Storage quality of minimally processed cabbage packaged in plastic films", Journal 
of Food Quality, Vol. 20 No. 5, pp 381-389.

Rodriguez., A., Gonzalez-salas, M. I., Soto-Vato-Valdez, H. and Silveria, M. I. (1992), "Effects of postharvest treatment on the quality of tuna during storage", Proceedings of the $3^{\text {rd }}$ Annual Texas Prickly Pear Council, pp. 9-21.

Sholberg, P., Haag, P., Hocking, R. and Bedford, K. (2000), "The use of vinegar vapor to reduce postharvest decay of harvested fruit", HortScience, Vol. 35 No. 5, pp. 898-903.

Snedecor, G. W. and Cochran, W. G. (1989), Statistical methods, $7^{\text {th }}$ Ed., The Iowa State University Press, Ames, lowa, USA, pp. 50.

Tanada-Palmu, P. S. and Grosso, C. R. (2005), "Effect of edible wheat gluten-based films and coatings on refrigerated strawberry (Fragaria ananassa) quality", Postharvest biology and technology, Vol. 36 No. 2, pp. 199-208.
Tesoriere, L., Butera, D., Allegra, M., Fazzari, M. and Livrea, M. A. (2005), "Distribution of betalain pigments in red blood cells after consumption of cactus pear fruits and increased resistance of the cells to ex vivo induced oxidative hemolysis in humans", Journal of Agricultural and Food Chemistry, Vol. 53 No. 4, pp. 12661270.

Velu, S., Abu Bakar, F., Mahyudin, N. A., Saari, N. and Zaman, M. Z. (2013), "Effect of modified atmosphere packaging on microbial flora changes in fishery products", International Food Research Journal, Vol. 20 No. 1, pp. 17-26.

Wong, D.W. S., Camirand, W.P. and Pavlath, A. E. (1994), "Development of edible coatings for minimally processed fruit and vegetables", In Krochta J. M., Baldwin E. A. and Nisperos-Carriedo M. O. (Eds.), Edible coatings and films to improve food quality, CRC Press, USA, pp. 65-88. 